\title{
ANALISIS PERBANDINGAN METODE TAM DAN METODE UTAUT 2 DALAM MENGUKUR KESUKSESAN PENERAPAN SIMRS PADA RUMAH SAKIT WIJAYA KUSUMA DKT PURWOKERTO
}

\author{
Fiby Nur Afiana ${ }^{1}$, Pungkas Subarkah ${ }^{2}$, A.Kholil Hidayat ${ }^{3}$ \\ ${ }^{1,3}$ Program Studi Sistem Informasi, Fakultas Ilmu Komputer, Universitas Amikom Purwokerto \\ ${ }^{2}$ Program Teknik Informatika, Fakultas Ilmu Komputer, Universitas Amikom Purwokerto \\ Jl. Let. Jend. Pol. Soemarto Purwanegara, Purwokerto, Banyumas, Jawa Tengah \\ Email : ${ }^{1}$ fiby@amikompurwokerto.ac.id, ${ }^{2}$ subarkah@amikompurwokerto.ac.id, ${ }^{3}$ kholil82@gmail.com
}

\begin{abstract}
ABSTRAK
Tuntunan mengenai pengembangan pelayanan kesehatan oleh masyarakat, secara tidak langsung meminta pihak manajemen dan pelaksana layanan kesehatan untuk memberikan pelayanan secara optimal dan profesional. Dengan bantuan sistem informasi diharapkan dapat membatu manajemen untuk tercapainya peningkatan pelayanan kesehatan. Penelitian ini bertujuan untuk menganalisis kesuksesan penerapan Sistem Informasi Manajemen Rumah Sakit (SIMRS) khususnya sistem informasi rekam medis yang diterapkan di Rumah Sakit Wijaya Kusuma DKT Purwokerto. Metode TAM dan UTAUT 2 digunakan oleh beberapa peneliti untuk mengukur kesuksesan penerapan sistem informasi berdasarkan keinginan pengguna/konsumen dalam menggunakan sistem informasi. Metode TAM dikembangkan untuk menjelaskan perilaku pengguna sistem informasi. Menempatkan faktor sikap dan tiap-tiap perilaku pemakai dengan konstruk. UTAUT 2 merupakan pengembangan dari metode sebelumnya yang bertujuan membantu perusahaan/organisasi untuk memahami bagaimana pemanfaatan teknologi informasi dalam mendukung kinerja perusahaan/organisasi Perbandingan hasil akhir kedua metode dilakukan untuk mengetahui sejauh mana kesuksesan penerapan sistem informasi dapat dijelaskan oleh kedua metode dengan melihat perbedaan hasil analisis yang dihasilkan. Hasil akhir menyatakan metode yang lebih baik digunakan dalam kesuksesan sistem informasi manajemen rumah sakit di Rumah Sakit Wijaya Kusuma DKT Purwokerto yaitu metode UTAUT 2 sebab metode metode UTAUT mampu mengukur sebanyak 2,109 sedangkan metode metode TAM hanya mengukur sebanyak 1,782 .
\end{abstract}

Kata Kunci - sistem informasi rekam medis, TAM, UTAUT 2

\begin{abstract}
Guidelines regarding the development of health services by the community indirectly require the management and executors of health services to provide services in an optimal and professional manner. With the help of information systems, it is expected to help management to achieve improved health services. This study aims to analyze the success of the application of the Hospital Management Information System (SIMRS), especially the medical record information system applied at Wijaya Kusuma Hospital, DKT Purwokerto. The TAM and UTAUT 2 methods are used by several researchers to measure the success of the application of information systems based on the wishes of users / consumers in using information systems. The TAM method was developed to explain the behavior of information system users. Placing attitude factors and each user behavior with the construct. UTAUT 2 is a development of the previous method which aims to help companies / organizations to understand how the use of information technology in supporting company / organizational performance Comparison of the final results of both methods is done to determine the extent to which the success of information systems can be explained by the two analysis results. produced. The final result stated that a better method was used in the success of the hospital management information system at Wijaya Kusuma Hospital, DKT Purwokerto, namely the UTAUT 2 method because the UTAUT method was able to measure 2,109 while the TAM method only measured 1,782.
\end{abstract}

Keywords - medical record information system, TAM, UTAUT 2

Author Korespondensi (Fiby Nur Afiana)

Email :fiby@amikompurwokerto.ac.id 


\section{PENDAHULUAN}

Penggunaan Teknologi Informasi di bidang kesehatan yang saat ini sedang tren dalam pelayanan kesehatan adalah penerapan Sistem Informasi Manajemen Rumah Sakit (SIMRS)[1][2]. Sistem ini disiapkan untuk menangani keseluruhan proses manajemen Rumah Sakit mulai dari pelayanan diagnosa, tindakan untuk pasien, medical report, apotek, gudang farmasi, penagihan, database personalia, penggajian karyawan, proses akutansi sampai dengan pengendalian oleh manajemen[3]. Sistem informasi rekam medis merupakan salah satu bagian dari Sistem Informasi Manajemen Rumah Sakit, dimana Sistem informasi rekam medik adalah proses yang berhubungan dengan pencatatan data yang ada pada pasien serta bagaimana mengelola dan melakukan pencarian kembali terhadap status pasien yang berisi: data identitas pasien, resume hasil anamnesi, resume hasil pemeriksaan fisik, resume terapi, alergi obat dan lain-lain[4][1][5]. Pengembangan sistem informasi ditujukan untuk mendukung ketersedian data informasi bagi manajemen dan pelaksana layanan kesehatan serta pengembangan jaringan informasi dan meminimalkan resiko yang cukup besar terhadap kerusakan dan kehilangan data pasien[6]. Tuntunan mengenai pengembangan pelayanan kesehatan oleh masyarakat, secara tidak langsung meminta pihak manajemen dan pelaksana layanan kesehatan untuk memberikan pelayanan secara optimal dan profesional[7]. Dengan bantuan sistem informasi diharapkan dapat membatu manajemen untuk tercapainya peningkatan pelayanan kesehatan. Keputusan pemanfaatan sistem informasi berada di tangan manajemen, tapi keberhalisan suatu penggunaan sistem informasi bergantung pada penggunaan dan penerimaan setiap individu pemakainya[8]. Untuk menghasilkan suatu evaluasi yang maksimal diperlukan suatu metode yaitu metode TAM dan UTAUT 2.

Metode TAM dan UTAUT 2 digunakan oleh beberapa peneliti untuk mengukur kesuksesan penerapan sistem informasi berdasarkan keinginan pengguna/konsumen dalam menggunakan sistem informasi tersebut. Metode TAM dikembangkan untuk menjelaskan perilaku pengguna sistem informasi[9]. Menempatkan faktor sikap dan tiap-tiap perilaku pemakai dengan konstruk yaitu persepsi kegunaan (perceived usefulness), kemudahan penggunaan (percieved ease of use) dan kondisi nyata pengguna sistem (actual system usage)[10]. Technology Acceptance Model (TAM) juga dikatakan sebagai metode yang digunakan untuk menjelaskan perilaku penerimaan pengguna terhadap teknologi[11]. Kelebihan dari metode ini adalah salah satu metode yang paling banyak digunakan untuk melakukan penelitiaan terhadap pengguna. Tujuan dari metode ini adalah untuk menjelaskan faktor-faktor dari perilaku pengguna terhadap penerimaan teknologi[12].

Unified Theory of Acceptance and Use of Technology 2 (UTAUT 2) merupakan pengembangan dari model UTAUT yang dilakukan oleh Venkates[13]. Tujuan adanya UTAUT 2 yakni untuk mempelajari penerimaan dan penggunaan teknologi dalam konteks konsumen[14]. Dalam UTAUT 2 terdapat penambahan 3 variabel baru dan menghilangkan 1 variabel moderator yaitu voluntariness of use yang berasal dari model UTAUT[15].

Penelitian ini bertujuan untuk menganalisis kesuksesan penerapan Sistem Informasi Manajemen Rumah Sakit (SIMRS) khususnya sistem informasi rekam medis yang diterapkan di Rumah Sakit Wijaya Kusuma DKT Purwokerto. Perbandingan hasil akhir kedua metode dilakukan untuk mengetahui sejauh mana kesuksesan penerapan sistem informasi dapat dijelaskan oleh kedua metode dengan melihat perbedaan hasil analisis yang dihasilkan oleh kedua metode.

\section{METODOLOGI}

Tahapan penelitian dilakukan untuk mempermudah dalam melakukan penelitian. Desain penelitian analisis sistem informasi rekam medis menggunakan metode TAM dan UTAUT 2 dapat dilihat pada gambar dibawah ini 


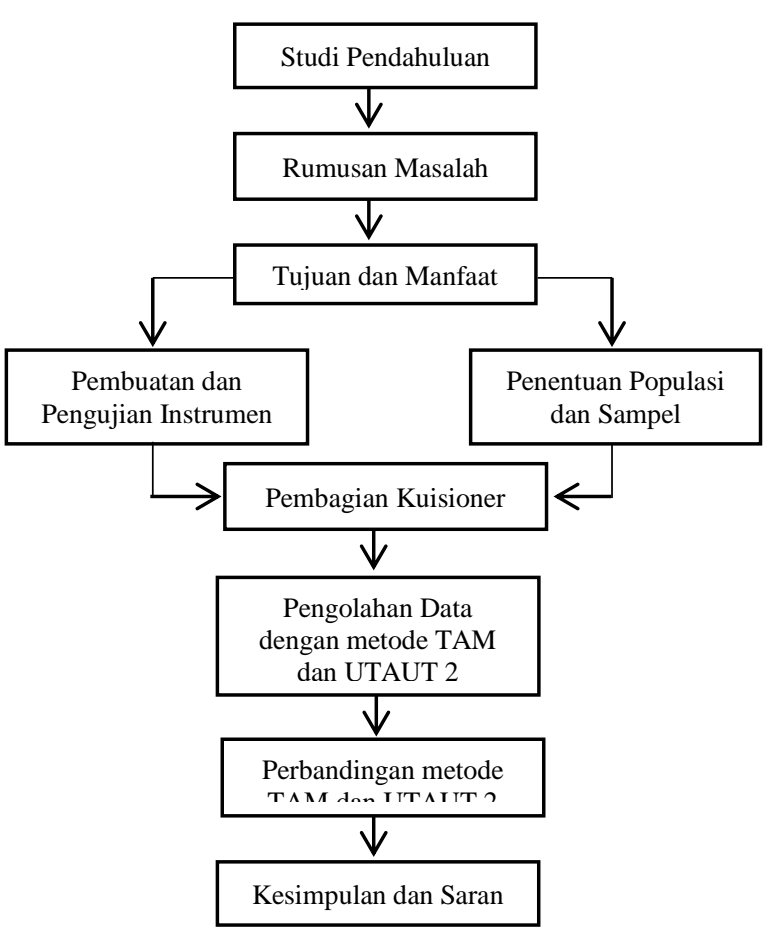

Gambar 1. Tahapan Penelitian

1. Studi Pendahuluan

Pada studi pendahuluan terdapat beberapa bagian seperti pencarian data melalui studi literature dan studi lapangan. Studi Literatur dilakukan dengan cara mencari informasi tentang metode TAM dan UTAUT 2, serta sistem informasi rekam medis yang digunakan oleh Rumah Sakit Wijaya Kusuma DKT Purwokerto. Studi lapangan terdiri atas metode observasi, dengan datang langsung ke lokasi penelitian dan melakukan wawancara terhadap stakeholder.

\section{Rumusan Masalah}

Rumusan masalah pada penelitian ini yaitu bagaimana membandingkan metode TAM dan UTAUT 2 untuk mengetahui metode mana yang terbaik dalam mengukur kesuksesan penerapan SIMRS di Rumah Sakit Wijayakusuma DKT Purwokerto.

\section{Tujuan Dan Manfaat}

Tujuan dari penyusunan penelitian ini adalah untuk mengetahui kesuksesan pengguna terhadap penerapan SIMRS dengan melihat perbedaan hasil dari metode TAM dan UTAUT 2 , untuk mengetahui metode yang terbaik dan layak dalam mengukur kesuksesan pengguna SIMRS. Manfaat yang akan diperoleh dengan adanya penelitian ini adalah dapat menerapkan metode terbaik dalam mengukur kesuksesan penerapan SIMRS di Rumah Sakit DKT Purwokerto dan dapat menjadi bahan masukan bagi pihak Rumah Sakit Wijayakusuma DKT dalam pengembangan Sistem Informasil Manajamen Rumah Sakit (SIMRS). Bagi peneliti dapat menambah khasanah ilmu pengetahuan wawasan tentang metode terbaik dalam mengukur kesuksesan penerapan SIMRS di Rumah Sakit Wijayakusuma DKT Purwokerto.

\section{Pembuatan dan Pengujian Instrumen}

Pada tahapan pembuatan dan pengujian instrumen terdapat variabel dan hipotesis penelitian.

a. Variabel penelitian metode TAM

Variabel TAM yang digunakan adalah

Perceived Ease of Use (PEOU), Perceived Usefulness (PU) dan Acceptance of System $(A O S)$. Indikator pada tiap variabel TAM sebagai berikut :

1) Perceived Ease of Use (PEOU)

Adapun indikator pernyataan sebagai berikut

a) Komputer sangat mudah dipelajari

b) Komputer mengerjakan dengan mudah apa yang di inginkan oleh pengguna.

c) Komputer sangat mudah untuk meningkatkan keterampilan pengguna.

d) Komputer sangat mudah untuk dioperasikan.

2) Perceived Usefulness (PU)

Adapun indikator pernyataan sebagai berikut :
a) Mempertinggi efektivitas
b) Menjadikan pekerjaan lebih mudah
c) Meningkatkan kinerja
d) Meningkatkan efisiensi

3) Acceptance of System (AOS)

Adapun indikator pernyataan sebagai berikut :
a) Menghemat waktu
b) Menyelesaikan tugas dengan bantuan teknologi
c) Ketertarikan terhadap sistem

b. Hipotesis penelitian metode TAM

Tabel 1. Tabel Uji Hipotesis Metode TAM

\begin{tabular}{|l|l|}
\hline No & Hipotesis \\
\hline $\mathrm{H}_{1}$ & $\begin{array}{l}\text { Perceived Ease of Use (PEOU) } \\
\text { berpengaruh signifikan terhadap Perceived } \\
\text { Usefulness (PU) }\end{array}$ \\
\hline $\mathrm{H}_{2}$ & $\begin{array}{l}\text { Perceived Ease of Use (PEOU) dan } \\
\text { Perceived Usefulness (PU) secara simultan }\end{array}$ \\
\hline
\end{tabular}


dan signifikan berpengaruh terhadap Acceptance of System (AOS)

c. Variabel penelitian metode UTAUT 2

Variabel UTAUT 2 yang digunakan adalah Performance Expentancy (PE), Effort Expectancy (EE), Social Influence (SI), Facilitating Conditions (FC) dan Habit $(\mathrm{H})$. Indikator pada tiap variabel UTAUT 2 sebagai berikut :

1) Performance Expentancy (PE),

Adapun indikator pernyataan sebagai berikut :
a) Keakuratan dalam input data
b) Hemat biaya saat menggunakan sistem informasi rekam medis
c) Waktu yang dibutuhkan dalam mengakses sistem tersebut.

2) Effort Expentancy (EE),

Adapun indikator pernyataan sebagai berikut :
a) Pemahaman pengguna sistem informasi rekam medis tersebut.
b) Pemahaman pengguna mengenai simulasi yang ada pada sistem informasi rekam medis.
c) Kemudahan yang dirasakan pengguna dalam menggunakan sistem
d) Kesiapan dan usaha pengguna dalam penggunaan sistem.

3) Social Influence (SI)

Adapun indikator pernyataan sebagai berikut :
a) Kebijakan rumah sakit dalam penggunaan sistem informasi rekam medis
b) Keharusan pengguna dalam penggunaan sistem rekam medis

4) Facilitating Conditions (FC)

Adapun indikator pernyataan sebagai berikut :
a) Disediakannya fasilitas untuk medis pengguna sistem informasi rekam
b) Ada bantuan jika mengalami kesulitan dalam menggunakan sistem informasi rekam medis

5) Habit $(\mathrm{H})$

Adapun indikator pernyataan sebagai berikut : b) Penggunaan sistem rekam medis menjadi kebutuhan sehingga menjadi kebiasaan.

d. Hipotesis penelitian metode UTAUT 2

Tabel 2. Tabel Uji Hipotesis Metode UTAUT 2

\begin{tabular}{|l|l|}
\hline $\mathrm{No}_{1}$ & \multicolumn{1}{|c|}{ Hipotesis } \\
\hline $\mathrm{H}_{1}$ & $\begin{array}{l}\text { Performance Expectancy (PE) berpengaruh } \\
\text { signifikan terhadap Effort Expectancy (EE) }\end{array}$ \\
\hline $\mathrm{H}_{2}$ & $\begin{array}{l}\text { Effort Expectancy (EE) berpengaruh } \\
\text { signifikan terhadap Sosial Influnce (SI) }\end{array}$ \\
\hline $\mathrm{H}_{3}$ & $\begin{array}{l}\text { Sosial Influnce (SI) berpengaruh } \\
\text { siignifikan terhadap Facilitating Condition } \\
\text { (FC) }\end{array}$ \\
\hline $\mathrm{H}_{4}$ & $\begin{array}{l}\text { Performance Expectancy (PE), Effort } \\
\text { Expectancy (EE Sosial Influnce (SI), dan } \\
\text { Facilitating Condition (FC) secara } \\
\text { sumultan berpengaruh signifikan terhadap } \\
\text { Habit (H) }\end{array}$ \\
\hline
\end{tabular}

\section{Sampel dan Populasi}

Sampel dan populasi dalam penelitian memiliki peranan yang sangat penting. Sampel sebagian dari populasi dengan karateristik yang akan diteliti dan populasi total keseluruhan dari satuan atau individu dengan karateristik yang akan diteliti. Pada penelitian ini untuk jumlah sampel disesuaikan dengan kondisi terdapat total 14 koresponden.

\section{6. $\quad$ Metode TAM dan UTAUT 2}

Kerangka kerja penelitian ini mengacu pada Metode TAM

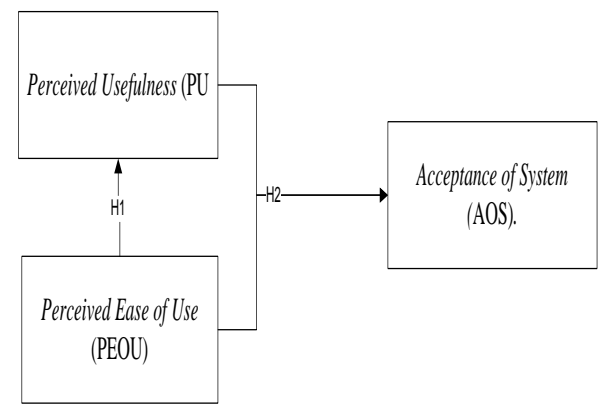

Gambar 2. Kerangka Kerja Penelitian Mengacu Metode TAM

Kerangka kerja penelitian ini mengacu pada Metode UTAUT 2 


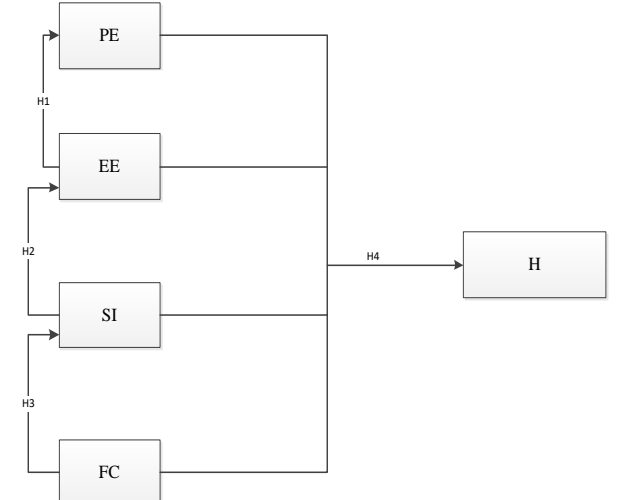

Gambar 3. Kerangka Kerja Penelitian Mengacu Metode UTAUT 2

7. Perbandingan Metode TAM dan UTAUT 2 Pada tahapan ini peneliti membandingkan hasil kedua metode untuk mendapatkan metode mana yang lebih tepat digunakan.

\section{HASIL DAN PEMBAHASAN}

1. Uji Validitas dan Reliabilitas

a. Uji Validitas Metode TAM

1) Uji Validitas variabel Perceived Ease of Use (PEOU)

Hasil uji Perceived Ease of Use (PEOU) dapat di ambil nilai Person Correlation-nya. Berikut penjabaran dari hasil dari masingmasing butir pertanyaannya.

Tabel 2. Hasil Uji Validitas variabel Perceived Ease of Use (PEOU)

\begin{tabular}{|c|c|c|c|c|c|}
\hline No & Pernyataan & $\begin{array}{l}\text { Simbol } \\
\text { Butir } \\
\text { Pernyat } \\
\text { aan }\end{array}$ & $\begin{array}{l}\text { Per } \\
\text { son } \\
\text { Cor } \\
\text { rela } \\
\text { tion }\end{array}$ & $\begin{array}{c}\text { rTabe } \\
1\end{array}$ & Hasil \\
\hline 1 & $\begin{array}{l}\text { Proses } \\
\text { pendaftara } \\
\text { n Rekam } \\
\text { Medis } \\
\text { untuk } \\
\text { mendiagno } \\
\text { sa penyakit } \\
\text { mudah } \\
\text { digunakan. }\end{array}$ & $\begin{array}{l}\text { PEOU1 } \\
\text { _Q1 }\end{array}$ & $\begin{array}{l}0.87 \\
7\end{array}$ & $\begin{array}{l}0.532 \\
4\end{array}$ & Valid \\
\hline 2 & $\begin{array}{l}\text { Saya dapat } \\
\text { memperole } \\
\text { h informasi } \\
\text { data } \\
\text { Rekam } \\
\text { Medis } \\
\text { terutama } \\
\text { pada } \\
\text { diagnosa } \\
\text { penyakit } \\
\text { dengan }\end{array}$ & $\begin{array}{l}\text { PEOU2 } \\
\text { _Q2 }\end{array}$ & $\begin{array}{l}0.80 \\
2\end{array}$ & $\begin{array}{l}0.532 \\
4\end{array}$ & Valid \\
\hline
\end{tabular}

mudah.

Dari hasil pengujian validitas variabel Perceived Ease of Use (PEOU) menunjukan nilai $r$ hitung lebih dari $\mathrm{r}$ tabel (0.5324) sehingga dapat dikatakan bahwa data variabel Perceived Ease of Use (PEOU) adalah valid.

1) Uji Validitas variabel Perceived Usefulness (PU)

Hasil uji Perceived Usefulness (PU) dapat di ambil nilai Person Correlation-nya. Berikut penjabaran dari hasil dari masingmasing butir pertanyaannya :

Tabel 3. Hasil Uji Validitas variabel PU

\begin{tabular}{|c|c|c|c|c|c|}
\hline $\begin{array}{l}\mathrm{N} \\
\mathrm{O}\end{array}$ & $\begin{array}{c}\text { Pernyataa } \\
n\end{array}$ & $\begin{array}{l}\text { Symbol } \\
\text { butir } \\
\text { pernyat } \\
\text { aan }\end{array}$ & $\begin{array}{l}\text { Person } \\
\text { Correlat } \\
\text { ion }\end{array}$ & $\begin{array}{c}\text { rTab } \\
\text { el }\end{array}$ & $\begin{array}{c}\text { Has } \\
\text { il }\end{array}$ \\
\hline 1 & 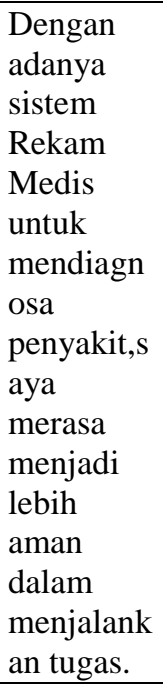 & $\begin{array}{c}\text { PU1_Q } \\
5\end{array}$ & 0.877 & $\begin{array}{c}0.53 \\
24\end{array}$ & $\begin{array}{c}\text { Vali } \\
\text { d }\end{array}$ \\
\hline 2 & $\begin{array}{l}\text { Sistem } \\
\text { Rekam } \\
\text { Medis } \\
\text { untuk } \\
\text { memperce } \\
\text { pat proses } \\
\text { pendaftara } \\
\text { n data } \\
\text { pasien. }\end{array}$ & $\begin{array}{l}\text { PU2_Q } \\
6\end{array}$ & 0.768 & $\begin{array}{l}0.53 \\
24\end{array}$ & $\begin{array}{l}\text { Vali } \\
\text { d }\end{array}$ \\
\hline 3 & $\begin{array}{l}\text { Dengan } \\
\text { adanya } \\
\text { sistem } \\
\text { Rekam } \\
\text { Medis, } \\
\text { meringan } \\
\text { kan tugas } \\
\text { saya. }\end{array}$ & $\begin{array}{l}\text { PU3_Q } \\
7\end{array}$ & 0.758 & $\begin{array}{l}0.53 \\
24\end{array}$ & $\begin{array}{l}\text { Vali } \\
\text { d }\end{array}$ \\
\hline 4 & $\begin{array}{l}\text { Fungsi } \\
\text { sistem } \\
\text { Rekam } \\
\text { Medis } \\
\end{array}$ & $\begin{array}{l}\text { PU4_Q } \\
8\end{array}$ & 0.747 & $\begin{array}{l}0.53 \\
24\end{array}$ & $\begin{array}{l}\text { Vali } \\
\text { d }\end{array}$ \\
\hline
\end{tabular}




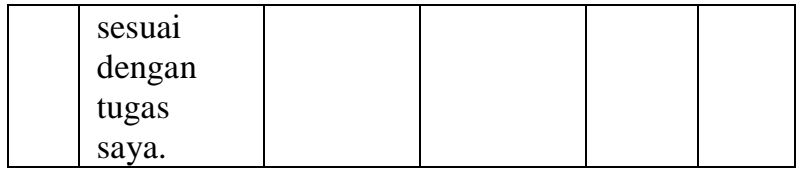

Dari hasil pengujian validitas variabel Perceived Usefulness (PU) menunjukan nilai $\mathrm{r}$ hitung lebih dari $r$ tabel (0.5324) sehingga dapat dikatakan bahwa data variabel Perceived Usefulness (PU) adalah valid.

2) Uji Validitas variabel Acceptance of System (AOS)

Hasil uji Acceptance of System (AOS) dapat di ambil nilai Person Correlation-nya. Berikut penjabaran dari hasil dari masing-masing butir pertanyaannya.

Tabel 4. Hasil Uji Validitas variabel Acceptance

\begin{tabular}{|c|c|c|c|c|c|}
\hline \multicolumn{6}{|c|}{ of System (AOS) } \\
\hline $\begin{array}{l}\mathrm{N} \\
\mathrm{O}\end{array}$ & Pernyataan & $\begin{array}{l}\text { Simbol } \\
\text { Butir } \\
\text { Pernyata } \\
\text { an }\end{array}$ & $\begin{array}{l}\text { Person } \\
\text { Correlat } \\
\text { ion }\end{array}$ & $\begin{array}{l}\text { rTab } \\
\text { el }\end{array}$ & $\begin{array}{l}\text { Has } \\
\text { il }\end{array}$ \\
\hline 1 & $\begin{array}{l}\text { Mengguna } \\
\text { kan Sistem } \\
\text { Rekam } \\
\text { Medis } \\
\text { mampu } \\
\text { menghema } \\
\text { t waktu } \\
\text { dalam } \\
\text { menyelesa } \\
\text { ikan } \\
\text { pekerjaan } \\
\text { kantor. }\end{array}$ & $\begin{array}{l}\text { AOS1_ } \\
\text { Q9 }\end{array}$ & 0.577 & $\begin{array}{l}0.53 \\
24\end{array}$ & $\begin{array}{l}\text { Val } \\
\text { id }\end{array}$ \\
\hline 2 & $\begin{array}{l}\text { Saya akan } \\
\text { selalu } \\
\text { mengguna } \\
\text { kan sistem } \\
\text { Rekam } \\
\text { Medis } \\
\text { untuk } \\
\text { mendiagno } \\
\text { sa } \\
\text { penyakit } \\
\text { untuk } \\
\text { menyelesa } \\
\text { ikan tugas } \\
\text { saya. }\end{array}$ & $\begin{array}{l}\text { AOS2 } \\
\text { Q10 }\end{array}$ & 0.883 & $\begin{array}{l}0.53 \\
24\end{array}$ & $\begin{array}{l}\text { Val } \\
\text { id }\end{array}$ \\
\hline 3 & $\begin{array}{l}\text { Saya } \\
\text { menyukai } \\
\text { sistem } \\
\text { Rekam }\end{array}$ & $\begin{array}{l}\text { AOS3 } \\
\text { Q11 }\end{array}$ & 0,931 & $\begin{array}{l}0.53 \\
24\end{array}$ & $\begin{array}{l}\text { Val } \\
\text { id }\end{array}$ \\
\hline
\end{tabular}

\begin{tabular}{|l|l|l|l|l|l|}
\hline Medis & & & & \\
untuk & & & & \\
mendiagno & & & & \\
sa & & & & \\
berbagai & & & & \\
penyakit. & & & & \\
\hline
\end{tabular}

Dari hasil pengujian validitas variabel Acceptance of System (AOS) menunjukan nilai $\mathrm{r}$ hitung lebih dari $r$ tabel (0.5324) sehingga dapat dikatakan bahwa data variabel variabel Acceptance of System (AOS) adalah valid.

b. Uji Reliabilitas Metode TAM

Uji reliabilitas pada penelitian ini menggunakan bantuan aplikasi SPSS Versi 23 dengan teknik uji alpha cronbach. Teknik ini dapat digunakan untuk menentukan apakah suatu instrumen penelitian reliabel atau tidak.

Tabel 5. Kesimpulan Uji Reliabilitas

\begin{tabular}{|c|c|c|c|c|}
\hline No & Variabel & $\begin{array}{c}\text { Cronbach's } \\
\text { Alpha }\end{array}$ & Hasil & Kriteria \\
\hline 1 & $\begin{array}{l}\text { Persepsi } \\
\text { Kemudahan } \\
\text { Penggunaan } \\
\text { (Perceived } \\
\text { Ease Of } \\
\text { Use) (X1) }\end{array}$ & 0.894 & $\begin{array}{c}\text { reliabel } \\
\text { atau } \\
\text { handal }\end{array}$ & $\begin{array}{l}\text { Sangat } \\
\text { Tinggi }\end{array}$ \\
\hline 2 & $\begin{array}{l}\text { Persepsi } \\
\text { Kegunaan } \\
\text { (Perceived } \\
\text { Usefulness) } \\
\text { (X2) }\end{array}$ & 0.888 & $\begin{array}{c}\text { reliabel } \\
\text { atau } \\
\text { handal }\end{array}$ & $\begin{array}{l}\text { Sangat } \\
\text { Tinggi }\end{array}$ \\
\hline 3 & $\begin{array}{l}\text { Kondisi } \\
\text { nyata } \\
\text { penggunaan } \\
\text { sistem } \\
\text { (Acceptance } \\
\text { of System) } \\
\text { (Y1) }\end{array}$ & 0.824 & $\begin{array}{c}\text { reliabel } \\
\text { atau } \\
\text { handal }\end{array}$ & $\begin{array}{l}\text { Sangat } \\
\text { Tinggi }\end{array}$ \\
\hline
\end{tabular}

Dari hasil pengujian relibilitas menunjukan semua nilai Cronbach's Alpha lebih dari 0,8. Sehingga dapat dikatakan bahwa data adalah reliabel atau handal.

2. Uji Hipotesis regresi sederhana metode TAM

a. Uji Hipotesis variabel Perceived Ease of Use (PEOU) terhadap Perceived Usefulness (PU).

Tabel 6. Hasil uji regresi variabel PEOU terhadap PU

\begin{tabular}{|l|c|}
\hline \multicolumn{1}{|c|}{ Keterangan } & Nilai \\
\hline T Hitung & 1,782 \\
\hline Signifikasi & 0,006 \\
\hline F Hitung & 10,805 \\
\hline
\end{tabular}




\begin{tabular}{|l|l|}
\hline R Square & 0,474 \\
\hline
\end{tabular}

b. Uji Hipotesis variabel Perceived Ease of Use (PEOU) dan Perceived Usefulness (PU) terhadap Acceptance of System (AOS).

Tabel 7. Hasil uji regresi variabel PEOU \& PU terhadap AOS

\begin{tabular}{|l|c|}
\hline \multicolumn{1}{|c|}{ Keterangan } & Nilai \\
\hline T Hitung PEOU & 3,716 \\
\hline $\begin{array}{l}\text { Signifikasi } \\
\text { PEOU }\end{array}$ & 0,003 \\
\hline T Hitung PU & 1,741 \\
\hline Signifikasi PU & 0,110 \\
\hline F Hitung & 24,465 \\
\hline R Square & 0,816 \\
\hline
\end{tabular}

c. Rangkuman Hipotesis

Tabel 8. Rangkuman Hipotesis

\begin{tabular}{|l|l|c|l|l|}
\hline No & Hipotesis & Uji F & Uji T & $\begin{array}{c}\text { Koefisien } \\
\mathrm{R}\end{array}$ \\
\hline 1 & H1 & $\begin{array}{l}\text { Diterima } \\
(10,805)\end{array}$ & Diterima & $47,4 \%$ \\
\hline 2 & H2 & $\begin{array}{l}\text { Diterima } \\
(24,465)\end{array}$ & $\begin{array}{l}\text { PEOU } \\
\text { diterima } \\
\text { PU } \\
\text { ditolak }\end{array}$ & $81,6 \%$ \\
\hline
\end{tabular}

Dari tabel diatas menunjukan bagaimana pengaruh dari masing-masing hipotesisi penelitian. Menurut hasil uji regresi menunjukan bahwa variabel yang memiliki pengaruh adalah variabel Perceived Ease of Use (PEOU) berpengaruh signifikan terhadap Perceived Usefulness (PU) hal ini dikarenakan saling berpengaruh antar variabel dan memiliki nilai signifikasi yang paling tinggi, Sedangkan hipotesis kedua dinyatakan diterima ditunjukan pada uji $\mathrm{F}$ yang menunjukan bahwa variable Perceived Ease of Use (PEOU) dan Perceived Usefulness (PU) secara simultan dan signifikan berpengaruh terhadap Acceptance of System (AOS) namun pada uji $\mathrm{T}$ hanya salah satu variable yang memiliki nilai pengaruh yaitu hanya Perceived Usefulness (PU).

Oleh karena itu dibutuhkan perbaikan untuk variabel Perceived Ease of Use (PEOU) dan Perceived Usefulness (PU) untuk meningkatkan penerimaan sistem paling tinggi.

3. Uji Validitas dan Uji Reliabilitas

a. Uji Validitas metode UTAUT 2
1. Uji variabel Expentancy $(\mathrm{PE})$

Tabel 9. Hasil Uji Variabel Performancy Expentancy $(\mathrm{PE})$

Dari hasil pengujian validitas variabel Performance Expentancy (PE) menunjukan nilai r-hitung lebih dari $\mathrm{r}$ tabel (0.5324) sehingga dapat dikatakan bahwa data variabel Performance Expentancy (PE) adalah valid.

2. Uji variabel Effort Expectancy (EE)

Tabel 10. Hasil uji variabel Effort Expenctancy (EE)

\begin{tabular}{|l|l|l|l|}
\hline $\begin{array}{l}\text { Pernyataa } \\
\mathrm{n}\end{array}$ & R-Hitung & $\begin{array}{l}\text { R-Tabel } \\
5 \%\end{array}$ & Hasil \\
\hline 1 & & & \\
\hline 2 & 0,694 & \multirow{4}{*}{0,5324} & Valid \\
\cline { 1 - 2 } & 0,951 & Valid \\
\cline { 1 - 1 } & 0,546 & & Valid \\
\hline 4 & 0,921 & & Valid \\
\hline
\end{tabular}

Dari hasil pengujian validitas variabel Effort Expentancy (EE) menunjukan nilai r-hitung lebih dari $r$ tabel (0.5324) sehingga dapat dikatakan bahwa data variabel Effort Expentancy (PE) adalah valid.

3. Uji variabel Social Influence (SI)

Tabel 11. Hasil Uji variabel Social Influence (SI)

\begin{tabular}{|c|c|c|c|}
\hline $\begin{array}{l}\text { Pernyataa } \\
\mathrm{n}\end{array}$ & R-Hitung & $\begin{array}{l}\text { R-Tabel } \\
5 \%\end{array}$ & Hasil \\
\hline 1 & 0,691 & \multirow{4}{*}{0,5324} & Valid \\
\hline 2 & 0,702 & & Valid \\
\hline 3 & 0,852 & & Valid \\
\hline 4 & 0,940 & & Valid \\
\hline
\end{tabular}
menunjukan nilai r-hitung lebih dari $\mathrm{r}$ tabel (0.5324) sehingga dapat dikatakan bahwa data variabel Social Influence (SI) adalah valid.

4. Uji variabel Facilitating Conditions (FC)

Tabel 12. Hasil Uji Variabel Facilitating Conditions (FC)

\begin{tabular}{|c|c|c|c|}
\hline $\begin{array}{l}\text { Pernyataa } \\
\mathrm{n}\end{array}$ & R-Hitung & $\begin{array}{l}\text { R-Tabel } \\
5 \%\end{array}$ & Hasil \\
\hline 1 & 0,871 & \multirow{4}{*}{0,5324} & Valid \\
\hline 2 & 0,601 & & Valid \\
\hline 3 & 0,579 & & Valid \\
\hline 4 & 0,602 & & Valid \\
\hline
\end{tabular}

Dari hasil pengujian validitas variabel Facilitating Conditions $(F C)$ menunjukan nilai r-hitung lebih dari rtabel (0.5324) sehingga dapat dikatakan 
bahwa data variabel Facilitating Conditions $(F C)$ adalah valid.

\begin{tabular}{|l|l|l|l|}
\hline Pernyataan & $\begin{array}{l}\mathrm{R}- \\
\text { hitung }\end{array}$ & $\begin{array}{l}\text { R- table } \\
5 \%\end{array}$ & Hasil \\
\hline 1 & 0,540 & & valid \\
\cline { 1 - 1 } 0,5324 & & valid \\
\cline { 1 - 1 } & 0,614 & valid \\
\cline { 1 - 1 } & 0,547 & & valid \\
\hline
\end{tabular}

5. Uji variabel Habit $(\mathrm{H})$

Tabel 13. Hasil Uji Variabel Habit

$(\mathrm{H})$

\begin{tabular}{|l|l|l|l|}
\hline $\begin{array}{l}\text { Pernyataa } \\
\mathrm{n}\end{array}$ & R-Hitung & $\begin{array}{l}\text { R-Tabel } \\
\mathbf{5 \%}\end{array}$ & Hasil \\
\hline 1 & 0,570 & \multirow{3}{*}{0,5324} & Valid \\
\cline { 1 - 1 } & 0,610 & Valid \\
\cline { 1 - 2 } 3 & 0,814 & Valid \\
\hline
\end{tabular}

Dari hasil pengujian validitas variabel Habit $(\mathrm{H})$ menunjukan nilai rhitung lebih dari r-tabel (0.5324) sehingga dapat dikatakan bahwa data variabel Habit $(\mathrm{H})$ adalah valid.

b. Uji Reliabilitas metode UTAUT 2

Tabel 14. Uji Reliabilitas

\begin{tabular}{|l|l|l|}
\hline $\begin{array}{l}\text { Cronbach's } \\
\text { Alpha }\end{array}$ & Hasil & Kriteria \\
\hline 0,513 & $\begin{array}{l}\text { Reliabel atau } \\
\text { Handal }\end{array}$ & Cukup \\
\hline
\end{tabular}

Dari hasil pengujian reliabilitas, bahwa nilai cronbach's alpha yaitu 0,513 pada variabel $\mathrm{PE}, \mathrm{EE}, \mathrm{SI}, \mathrm{FC}$ dan $\mathrm{H}$, maka dinyatakan reliabel dengan kriteria cukup.

4. Uji Hipotesis metode UTAUT 2

a. Uji F-Test

Pada uji F-Test digunakan untuk mengetahui pengaruh dua variabel independen atau lebih secara simulttan terhadap variabel dependen.

Tabel 15. Hasil Uji T-Test

\begin{tabular}{|l|l|l|}
\hline Hipotesis & F-hitung & F-tabel \\
\hline H4 & 2,650 & 3,89 \\
\hline
\end{tabular}

Dari hasil pengujian pada tabel 15 ., menunjukan bahwa nilai F-hitung < Ftabel atau 2,650<3,89. Dapat disimpulkan bahwa variabel PE,EE,SI, dan FC secara simultan tidak berpengaruh terhadap variabel $\mathrm{H}$.

b. Uji T-Test

Pada uji T-Test digunakan untuk mengetahui pengaruh variabel independen secara parsial terhadap variabel dependen.

Tabel 16. Hasil Uji T-Test

\begin{tabular}{|c|c|c|}
\hline Hipotesis & T-hitung & T-tabel \\
\hline $\mathrm{H} 1$ & 1,155 & \multirow{3}{*}{1,782} \\
\hline $\mathrm{H} 2$ & 2,109 & \\
\hline $\mathrm{H} 3$ & 1,611 & \\
\hline
\end{tabular}

Dari hasil pengujian pada tabel 16 ., menunjukan bahwa $\mathrm{H} 1$ yaitu tidak ada pengaruh variabel Performance Expectancy terhadap Effort Expectancy, H2 yaitu ada pengaruh variabel Effort Expectancy terhadap Social Influence, dan H3 yaitu tidak ada pengaruh dari variabel Social Influence terhadap variabel Facilitating Conditions.

\section{SIMPULAN DAN SARAN}

1. Simpulan

a. Dari hasil penelitian untuk metode TAM (Theory Acceptance Model) hasil pengujian yang paling berpengaruh terhadap kesuksesan sistem rekam medis manajemen rumah sakit ialah pada variabel Perceived Ease of Use (PEOU) dengan angka statistik mencapai 1,782 lebih baik dibandingkan dengan variabel-variabel yan lain.

b. Dari hasil penelitian untuk metode UTAUT 2 (Unified Theory of Acceptance and Use of Technology 2) hasil pengujian yang paling berpengaruh terhadap kesuksesan sistem rekam medis manajemen rumah sakit ialah pada variabel Effort Expectancy (EE) dengan angka statistik mencapai 2,109 lebih baik dibandingkan dengan variabelvariabel yan lain.

c. Dari hasil penelitian maka metode yang lebih baik digunakan dalam kesuksesan sistem informasi manajemen rumah sakit di Rumah Sakit Wijaya Kusuma DKT Purwokerto yaitu metode UTAUT 2 (Unified Theory of Acceptance and Use of Technology 2) sebab metode metode UTAUT 2 (Unified Theory of Acceptance and Use of Technology 2) mampu mengukur sebanyak 2,109 
2. Saran

sedangkan metode metode TAM (Theory Acceptance Model) hanya mengukur sebanyak 1,782 .

a. Melakukan penambahan konstruk untuk mengetahui bagaimana pengaruh variabel lain terhadap sistem informasi rekam medis pada diagnosa penyakit.

b. Melakukan modifikasi metode Technology Acceptance Model (TAM) dan Unified Theory of Acceptance and Use of Technology 2 (UTAUT 2) untuk mengetahui bagaimana penerimaan dan kesesuaian tugas dari sistem informasi rekam medis pada diagnosa penyakit.

\section{REFERENSI}

[1] O. A. Putra and S. D. Rizki, "Analisa Perancangan Sistem Informasi Rekam Medis Test Narkoba Pada Mahasiswa Baru Upi Yptk Padang 2017,” J. Teknol., vol. 7, no. 1, pp. 152-155, 2017.

[2] D. Setyawan, "Analisis Implementasi Pemanfaatan Sistem Informasi Manajemen Rumah Sakit (Simrs) Pada Rsud Kardinah Tegal," Indones. J. Comput. Inf. Technol., vol. 1, no. 2, pp. 54-61, 2016.

[3] M. M. Sari, G. Y. Sanjaya, and A. Meliala, "EVALUASI SISTEM INFORMASI MANAJEMEN RUMAH SAKIT ( SIMRS ) DENGAN KERANGKA HOT - FIT," Semin. Nas. Sist. Inf. Indones., no. November, 2016.

[4] A. Prasetyo and M. S. Azis, "Perancangan sistem informasi rekam medis pada puskesmas jomin berbasis web," J. Interkom, vol. 13, no. 2, pp. 3138, 2018.

[5] I. Sudirahayu and A. Harjoko, "Analisis Kesiapan Penerapan Rekam Medis Elektronik Menggunakan DOQ-IT di RSUD Dr. H. Abdul Moeloek Lampung," J. Inf. Syst. Public Heal., vol. 1, no. 2, pp. 35-43, 2016.

[6] M. Riyan Nendyari Yufrizal, F. Renaldi, and F. Rakhmat Umbara, "Sistem Informasi Pelayanan Fasilitas Kesehatan Tingkat 1 ( Puskesmas ) Terintegrasi Kota Cimahi," Pros. Semin. Nas. Komput. dan Inform., vol. 2017, pp. 163168, 2017.

[7] T. Muryanti, M. Pinilih, and D.
Oktaviana, "EVALUASI SISTEM INFORMASI MANAJEMEN RUMAH SAKIT ( SIMRS ) PADA RSIA BUNDA ARIF PURWOKERTO MENGGUNAKAN FRAMEWORK COBIT 5," J. Probisnis, vol. 11, no. 2, pp. 59-75, 2018.

[8] I. Setiawan, B. D. Putranto, and E. W. Purwaningsih, "ANALISIS PERBANDINGAN METODE TAM DAN UTAUT TERHADAP PENERIMAAN PENGGUNA EOFFICE DI DPRD BANYUMAS," $J$. Teknovasi, vol. 05 , no. 2, pp. 14-25, 2018.

[9] P. Surendram, "Technology Acceptance Mdel: A Survey of Literature," Int. J. Bus. Soc. Res., vol. 2, no. 4, pp. 175-178, 2012.

[10] H. Hamrul, B. Soedijono, and A. Amborowati, "Analisis perbandingan metode TAM dan UTAUT dalam mengukur kesuksesan penerapan sistem informasi akademik," Semin. Nas. Inform. 2013), pp. 140-146, 2013.

[11] W. P. P. Handayani and M. Harsono, "Aplikasi Technology Acceptance Model (TAM) Pada Komputerisasi Kegiatan Pertanahan," J. Econ., vol. 12, no. 1, pp. 13-22, 2016.

[12] N. N. K. Yasa, L. P. R. A. Ratnaningrum, and P. G. Sukaatmadja, "THE APPLICATION OF TECHNOLOGY ACCEPTANCE MODEL ON INTERNET BANKING USERS IN THE CITY OF DENPASAR," J. Manaj. Dan Kewirausahaan, vol. 16, no. 2, pp. 93 102, 2014.

[13] V. Venkatesh, J. Y. L. Thong, and X. Xu, "CONSUMER ACCEPTANCE AND USE OF INFORMATION TECHNOLOGY: EXTENDING THE UNIFIED THEORY OF ACCEPTANCE AND USE OF TECHNOLOGY," MIS $Q$. , vol. 36, no. 1, pp. 157-178, 2012.

[14] Sutanto, I. Ghozali, and R. S. Handayani, "FAKTOR-FAKTOR YANG MEMENGARUHI PENERIMAAN DAN PENGGUNAAN SISTEM INFORMASI PENGELOLAAN KEUANGAN DAERAH (SIPKD) DALAM PERSPEKTIF THE UNIFIED THEORY OF ACCEPTANCE AND USE OF TECHNOLOGY 2 (UTAUT 2) DI KABUPATEN SEMARANG," $J$. 
Akutansi dan Audit., vol. 15, no. 1, pp. 37-68, 2018.

[15] A. M. Putranto and Y. Pramudiana, "Pengaruh Faktor-Faktor dalam Modifikasi Unified Theory of Acceptance and Use of Technology 2 terhadap Perilaku Konsumen dalam Mengadopsi Layanan Wifi PT. XYZ area Jakarta," e-Proceeding Manag., vol. 2, no. 2, pp. 1085-1094, 2015. 